\title{
Activity Assay of Etanol Extract of Lansau as Antihyperlipidemic
}

\section{Ruslin Ruslin*, Henny Kasmawati, Suryani Suryani, Sunandar Ihsan, Desi Sartina}

\author{
Faculty of Pharmacy, Universitas Halu Oleo, Sulawesi Tenggara, Indonesia
}

Submitted 23 May 2019; Revised 8 October 2019; Accepted 8 October 2019; Published 18 October 2019

*Corresponding author: mahaleo241@yahoo.co.id

\begin{abstract}
Hyperlipidemia is a condition due to increased levels of total cholesterol such as triglycerides, Low Density Lipoprotein (LDL) and decreased levels of High Density Lipoprotein (HDL). Hyperlipidemia can trigger wall thickening and narrowing of arteries, cause the abnormality of fat metabolism in the blood and creates chronic disease. Lansau herb of the Muna tribe of Southeast Sulawesi consists of 44 ingredients of medicinal plants empirically used to treat various diseases such as cholesterol. The aim of this study was to determine the effect of ethanolic extract of lansau to the hispatology of the liver that had hyperlipidemia. Mice were induced by cholesterol and high-fat feed. 24 wistar rats were divided into 6 groups consisting of normal control (1\% Na CMC), cholesterol and high fat diet food induction control, positive control (simvastatin $0.4 \mathrm{mg} / \mathrm{kgbw}$ ), group 1 (dose $6.907 \mathrm{mg} / \mathrm{kgbw}$ ) group II (dose $13.814 \mathrm{mg} / \mathrm{kgbw}$ ), group III (dose $27.628 \mathrm{mg} / \mathrm{kgbw}$ ). After 14 days, hispatological datas of liver were observed. The results showed that the ethanol extract of lansau had the potential activity as antihyperlipidemia, and cell repairing, especially in administering doses of $27.628 \mathrm{mg} / \mathrm{kgbw}$ and had not much different effectiveness from simvastatin group in reducing fat degeneration and cell death.
\end{abstract}

Keywords: aterosclerosis, hyperlipidemic, lansau, simvastatin

\section{Uji Aktivitas Ektrak Etanol Lansau sebagai Antihiperlipidemia}

\begin{abstract}
Abstrak
Hiperlipidemia merupakan kondisi akibat peningkatan kadar kolesterol total seperti trigliserida, LDL, serta penurunan kadar HDL. Hiperlipidemia dapat memicu penebalan dinding dan penyempitan pembuluh darah arteri, menimbulkan gangguan metabolisme lemak dalam darah sehingga menimbulkan penyakit kronis. Lansau ramuan khas suku Muna Sulawesi Tenggara terdiri dari 44 bahan tumbuhan obat secara empiris mampu mengobati berbagai penyakit dalam seperti kolesterol. Penelitian bertujuan untuk mengetahui pengaruh pemberian ekstrak etanol lansau terhadap hispatologi organ hati yang mengalami hiperlipidemia. Tikus diinduksi kolesterol dan pakan tinggi lemak. 24 ekor tikus wistar dibagi kedalam 6 kelompok, terdiri dari kontrol normal (Na CMC 1\%), kontrol induksi kolesterol dan makanan diet lemak tinggi, kontrol pembanding (simvastatin 0,4 mg/kgbb), kelompok 1 (dosis 6,907 $\mathrm{mg} / \mathrm{kgbb}$ ), kelompok II ( dosis 13,814 mg/kgbb), kelompok III (dosis 27,628 mg/kgbb). Setelah 14 hari perlakuan diamati perubahan hispatologi organ hati tikus berupa adanya degenerasi lemak dan kematian sel. Hasilnya, ekstrak etanol lansau berpotensi sebagai antihiperlipidemia, dan perbaikan sel terutama pada dosis $27,628 \mathrm{mg} / \mathrm{kgbb}$ dengan efektivitas yang tidak berbeda jauh dengan simvastatin dalam mengurangi degenerasi lemak dan kematian sel.
\end{abstract}

Kata Kunci: aterosklerosis, hiperlipidemia, lansau, simvastatin 


\section{Pendahuluan}

Hiperlipidemia adalah kondisi yang dialami seseorang akibat peningkatan kadar lipid atau lipoprotein dalam darah. Lipid adalah lemak dalam aliran darah, yang terdiri dari kolesterol dan trigliserida. Kolesterol bersirkulasi dalam aliran darah sebagai pelopor biosintesis hormon seks seperti hormon testosteron, hormon estrogen dan sebagai prekusor dari pengeluaran asam empedu yang disintesis dalam hati dan menyerap trigliserida dan vitamin larut lemak dari makan. Trigliserida (TG) sangat dibutuhkan oleh tubuh sebagai cadangan energi ketika seseorang tidak mendapat asupan energi yang cukup, dan tersimpan dalam sel-sel lemak. Keberadaan lemak sangat dibutuhkan oleh tubuh dalam kondisi normal. Namun hiperlipidemia (jumlah abnormal lipid dalam darah) merupakan faktor penyebab terjadinya aterosklerosis, terutama karena peningkatan LDL sehingga menyebabkan endotel menjadi hiperpermeabel. Hiperlipidemia kronis, terutama hiperkolesterolemia, dapat mengganggu fungsi endotel melalui peningkatan pembentukan radikal bebas yang mendeaktivasi nitrat oksida, dan terjadi perubahan kimiawi lemak yang dipicu oleh adanya radikal bebas sehingga LDL teroksidasi (LDL-oks), LDL-oks kemudian ditangkap oleh makrofag melalui scavening receptor secara terus menerus dan makrofag berubah menjadi sel busa kemudian sel busa membentuk fatty streak (bercak perlemakan) dihati.

Peningkatan kadar kolesterol berperan dalam produksi radikal bebas yang diaktifkan oleh reaksi oksidatif (ROS), reaksi ini dapat menyebabkan kerusakan makromolekul biologi yang meliputi oksidasi low density lipoprotein (oxidized-LDL), trigliserida, disfungsi endotelia dan peningkatan respons inflamasi yang berawal dari teroksidasinya asam lemak tak jenuh pada lapisan lipid menyebabkan kerusakan membran sel. ${ }^{2}$

Masyarakat dalam mengatasi timbulnya hiperlipidemia pada seseorang kebanyakan menggunakan obat-obat sintetik seperti klofibrat, statin yang terbukti dapat menurunkan kadar kolesterol akan tetapi obat- obat ini dapat menimbulkan efek samping seperti gangguan pencernaan, miopati, dan kemerahan pada kulit. ${ }^{3}$ Oleh karena itu, selain menggunakan obat-obat medis memiliki efek samping. Kebanyakan masyarakat menggunakan obat herbal atau ramuan, salah satu ramuan yang sudah dikenal secara luas khususnya masyarakat Muna Sulawesi Tenggara adalah ramuan lansau yang sudah terbukti secara empiris dapat mengobati beberapa penyakit dalam seperti kolesterol, diabetes, tekanan darah tinggi dan berbagai penyakit degeneratif lainnya. ${ }^{4}$ Ramuan lansau merupakan obat tradisional yang sangat populer di masyarakat suku Muna Sulawesi Tenggara, ramuan ini terdiri dari 44 jenis tumbuhan yaitu : tumbuhan Bhangkudu (Morinda citirfolia L.), Kamena-mena (Clerodendrum sp.), Patirangka (Impatiend balsamina L.), Soni (Dillenia cf. Celebica H.), Katapi (Sandoricum koetjape Merr.), Libbho (Ficus septica Burn.), Ghontoghe (Kleinhovia hospita L.), Daru (Averrhoa bilimbi L.), Lansale (Hyptis capitata Jacq.), Kaghai-ghai (Phyllanthus niruri L.), Sirikaya (Annona muricata L.), ramuan tersebut diramu secara dakota.

Berdasarkan latar belakang maka penelitian ini memberikan landasan ilmiah yang memadai untuk pengujian ektrak etanol lansau sebagai antihiperlipidemia, dengan pemeriksaan hispatologi organ hati tikus setelah pemberian ekstrak lansau dengan dosis secara bertingkat.

\section{Metode}

2.1. Alat

Rotary vacuum evaporator (Rotavapor, Buchi $\left.{ }^{\circledR}\right)$, blender (Philips), timbangan analitik (Precisa $\left.{ }^{\circledR}\right)$, gelas ukur (pyrex), ektromantel (Stuart®), 1 set alat refluks, corong (Pyrex, gelas kimia (Pyrex $\AA$ ), labu takar (Pyrex $\left.{ }^{\circledR}\right)$, Spoit dan kanula untuk pemberian ekstrak secara oral dan alat untuk pembuatan preparat histologi hepar, yaitu: Talenan, pisau scalpel, pinset, tissue cassette, mesin processor otomatis, mesin vacuum, mesin blocking, freezer $\left(-20^{\circ} \mathrm{C}\right)$, mesin microtome, pisau microtome, waterbath $50^{\circ} \mathrm{C}$, mikrotube, sentrifugasi, kaca objek, 
kaca penutup, rak khusus untuk pewarnaan, oven $50^{\circ} \mathrm{C}$, mikroskop.

\subsection{Bahan}

Ramuan Lansau terdiri dari tumbuhan Bhangkudu (Morinda citirfolia L.), Kamenamena (Clerodendrum sp.), Patirangka (Impatiend balsamina L.), Soni (Dillenia $\mathrm{cf}$. Celebica H.), Katapi (Sandoricum koetjape Merr.), Libbho (Ficus septica Burn.), Ghontoghe (Kleinhovia hospita L.), Daru (Averrhoabilimbi L.), Lansale (Hyptis capitata Jacq.), Kaghai-ghai (Phyllanthus niruri L.), Sirikaya (Annona muricata L.), Kumbou ( $A$. teysmanni), Patiwala ngkadea (L. camara), Ghondu (C. cujute), Kulidawa (T. grandis), Bumalaka (P.guajava), Kaghuse-ghuse (D. stipulacea), Sau bandara (S. alata), Ladha (Zingiber sp.), Wonta (S. laevis), Tongkoea (A. scholaris), Komba-komba (C. odorata), Tumbuhan P. indicus, Daun Blumea sp., Daun A. paniculata, Daun $S$. grandifora, Herba $E$. Indica, Daun M. Calabura, Daun S. oleosa, Rimpang I. Cylindrica, Biji A. Catechu, Batang T. Crispa, Batang D. Parsisora, Kumis kucing (O. aristatus Blume), Rogili (P. betle), Padamalala (C. citratus (DC) Stapf.), Ntangantanga ( $J$. curcas L.), Kasape ( $F$. stroblifera L.), Kalamandinga (L. leucocephala Lam.), Tulasi (O. tenuiflorum L.), Kabote-bote ( $R$. tuberose L.), Kaembu-embu (B. balsamifera L.), Kula (A. altilis), Rogo (P. cardifolia). Simvastatin, Na CMC, PTU, pakan tinggi lemak (kuning telur bebek 5\%, lemak kambing $10 \%$, minyak kelapa $1 \%$, dan pakan standar $83 \%$ ), kolesterol murni $1 \%$, alkohol $70 \%, 80 \%, 90 \%, 96 \%$, dan $100 \%$, aquades, parrafin cair, xylol, kloroform, dapar formalin $10 \%$, pewarna Haematoxylin dan Eosin, tikus jantan galur wistar (Rattus novergicus).

\subsection{Prosedur rinci}

2.3.1. Penyiapan sampel dan pembuatan ekstrak Lansau

Sampel ramuan Lansau diambil di hutan Batalaiworu wilayah Kabupaten Muna Provinsi Sulawesi Tenggara. Preparasi dilakukan dengan cara sortasi basah, pencucian, perajangan, sortasi kering, dan penghalusan. Sebanyak $500 \mathrm{~g}$ serbuk simplisia diekstraksi menggunakan metode refluks dengan pelarut etanol 96\%. Hasil refluks kemudian dipekatkan mengggunakan vacuum rotary evaporator pada suhu $50^{\circ} \mathrm{C}$ dan waterbath hingga diperoleh ekstrak etanol tumbuhan Lansau.

\subsubsection{Penyiapan hewan uji}

Hewan uji yang digunakan merupakan tikus putih jantan galur wistar yang dikembangbiakkan di LPPT-Bidang Pelayanan Penelitian Pra-Klinik dan Pengembangan Hewan Percobaan UGM Yogyakarta. Kemudian hewan coba tersebut dilakukan aklimatisasi selama 7 hari dengan pemberian pakan standar dan minuman aquades serta dilakukan pengamatan terhadap tingkah laku dan kondisi kesehatan hewan coba lalu dilakukan penimbangan berat badan setelah masa aklimatisasi.

2.3.3. Pengelompokkan hewan coba dan pemodelan tikus hiperlipidemia

Hewan uji sebanyak 24 ekor dikelompokkan menjadi 6 kelompok yang terdiri dari kelompok Kontrol Normal (KN) yaitu kelompok hewan sehat (tidak diinduksi hiperlipidemia) yang diberi NaCMC 1\%, Kelompok Kontrol Negatif (K()) yaitu kelompok hewan yang diinduksi hiperlipidemia dan diberi Na-CMC 1\%+ Makanan Diet Lemak Tinggi, Kelompok Kontrol Positif $(\mathrm{K}(+))$ yaitu kelompok hewan yang diinduksi hiperlipidemia dan diberi simvastatin $0,40 \mathrm{mg} / 200 \mathrm{gbb}$, kelompok LS I yaitu kelompok hewan yang diinduksi hiperlipidemia dan diberi ekstrak etanol lansau dengan dosis $6,90 \mathrm{mg} / \mathrm{kgbb}$, Kelompok LS II yaitu kelompok hewan yang diinduksi hiperlipidemia dan diberi ekstrak etanol lansau dengan dosis 13,81 mg/kgbb, Kelompok LS III yaitu kelompok hewan yang diinduksi hiperlipidemia dan diberi ekstrak etanol lansau dengan dosis 27,62 $\mathrm{mg} / \mathrm{kgbb}$. Masing-masing kelompok terdiri dari 4 ekor tikus (rumus fredere $(\mathrm{t}-1)(\mathrm{n}-1)>$ 15). Kemudian dilakukan pemodelan tikus hiperlipidemia, Tikus diinduksikan secara oral menggunakan kolesterol murni 2\% tiap 3 hari selama 14 hari, PTU 2,04 mg/kgbb 
ad libithium selama 14 hari dan Makan Diet Tinggi Lemak (MDLT) $10 \mathrm{~kg}$ mengandung tepung terigu $2 \mathrm{~kg}$, tepung ikan $1 \mathrm{~kg}$, tepung kacang hijau 500 gram, tepung jagung 1,5 kg, telur itik $1 \mathrm{~kg}$, telur puyuh $1 \mathrm{~kg}$, lemak sapi $1,5 \mathrm{~kg}$, hati ayam 500 gram dan mentega $1 \mathrm{~kg}$ dibrikan selama 14 hari.

\subsubsection{Analisis histopatologi}

Pengambilan organ hati dan pembuatan preparat histopatologi. Hewan uji dianastesi dengan menggunakan kloroform, lalu tikus dibedah di bagian abdomen dan diambil organ hatinya bagian lobus kanan dan dicuci dengan $\mathrm{NaCl}$ fisiologis $0,9 \%{ }^{6}$ Kemudian dibuat sediaan histopatologi berdasarkan metode Kieman:

a. Fiksasi jaringan dengan cara merendam dalam formalin buffer fosfat $10 \%$ selama 24 jam, kemudian diiris (trimming) agar dapat dimasukkan dalam kotak untuk diproses dalam tissue processor.

b. Dehidrasi jaringan yang berada di dalam kaset dimasukkan ke dalam tissue processor untuk dilakukan dehidrasi. Proses dehidrasi dilakukan menggunakan alkohol dengan konsentrasi bertingkat yang terdiri dari alkohol 70\%, 80\%, 90\%, 96\%, toluene 1 dan toluene 2 masing-masing selama 2 jam. Selanjutnya dijernihkan (clearing) dengan memasukkan sediaan ke dalam xylol I, xylol II dan xylol III.

c. Perendaman (embending) dan pencetakan (bloking) jaringan dimasukkan ke dalam paraffin cair dengan suhu $56^{\circ} \mathrm{C}$ selama 2 jam sebanyak 2 kali. Jaringan kemudian diambil dengan pinset, dilanjutkan dengan pemblokan menggunakan parafin blok.

d. Pemotongan (cutting) dilakukan dengan mikrotom ketebalan 4-5 $\mu \mathrm{m}$. Jaringan yang terpotong dikembangkan di atas air dalam waterbath, kemudian ditangkap dengan gelas objek. Lalu dikeringkan pada suhu kamar dan preparat siap diwarnai dengan Hematoxylin Eosin (HE).

e. Pewarnaan Hematoksilin Eosin (HE). Preparat di atas gelas objek direndam dalam xylol I 5 menit, dilanjutkan xylol II, III masing-masing 5 menit. Kemudian preparat direndam dalam alkohol $100 \%$ I dan II masingmasing 5 menit, selanjutnya ke dalam aquades, lalu direndam dalam Harris Hematoxylin selama 15 menit. Dicelupkan ke dalam aquades dengan cara mengangkat dan menurunkannya. Preparat kemudian dicelupkan ke dalam acid alkohol 1\% selama 7-10 celupan, direndam dalam aquades 15 menit, dan dalam eosin selama 2 menit. Selanjutnya preparat direndam dalam alkohol 96\% I dan II masing-masing 3 menit, alkohol $100 \%$ I dan II masingmasing 3 menit, dan dalam xylol IV dan V masing-masing 5 menit. Preparat dikeringkan dan dilakukan mounting dengan menggunakan entelan. Preparat diperiksa di bawah mikroskop untuk pemeriksaan terhadap perubahan histopatologi. $^{5}$

Tabel 1. Persentase hepatosit yang mengalami degenerasi lemak dan mengalami kematian pada tiap lapang pandang

\begin{tabular}{clccc}
\hline No & \multicolumn{1}{c}{ Kelompok percobaan } & Sel normal (\%) & Degenerasi lemak (\%) & Nekrosis (\%) \\
\hline 1 & A. Kondisi sesudah permodelan & 20 & 35 & 20 \\
2 & B. Setelah terapi & & & \\
& K. Normal & 47 & 0 & 0 \\
& K. negative & 21 & 63 & 20 \\
& K. positif & 50 & 5 & 5 \\
& K. dosis LS I & 26 & 11 & 5 \\
& K. dosis LS II & 30 & 15 & 10 \\
& K. dosis LS III & 60 & 0 & 0 \\
\hline
\end{tabular}




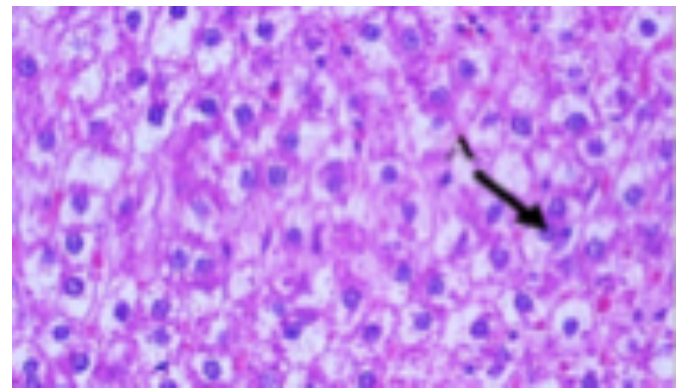

(a)

Gambaran histologi sel hati tikus wistar kelompok kontrol normal menunjukkan sel masih normal, (A) Sel normal.

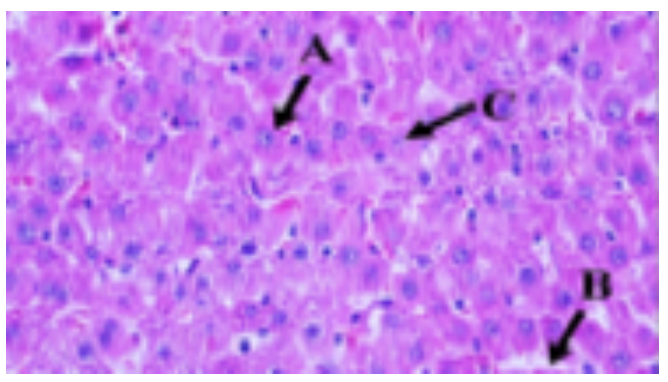

(c)

Gambaran histologi sel hati tikus wistar kelompok kontrol positif menunjukkan sel mengalami perbaikan dengan berkurangnya degenerasi lemak dan nekrosis serta bertambahnya sel hepatosit normal. (A) Sel Normal, (B) Degenerasi lemak, (C) Nekrosis.

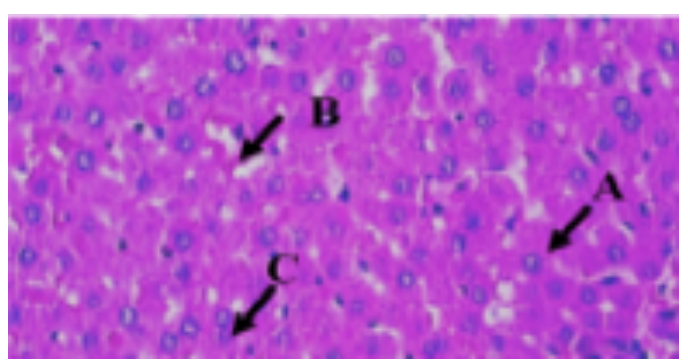

(e)

Gambaran histologi sel hati tikus wistar kelompok Dosis LS II menunjukkan sel mengalami perbaikan dengan berkurangnya degenerasi lemak dan nekrosis, serta bertambahnya sel hepatosit normal. (A) Sel Normal, (B) Degenerasi lemak, (C) Nekrosis.

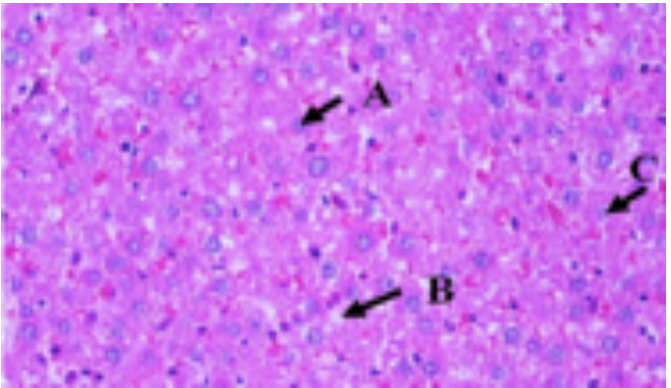

(b)

Gambaran histologi sel hati tikus wistar kelompok kontrol negatif, menunjukkan sel mengalami kerusakan berupa banyaknya degenerasi lemak dan nekrosis . (A) Sel Normal, (B) Degenerasi lemak, (C) Nekrosis.

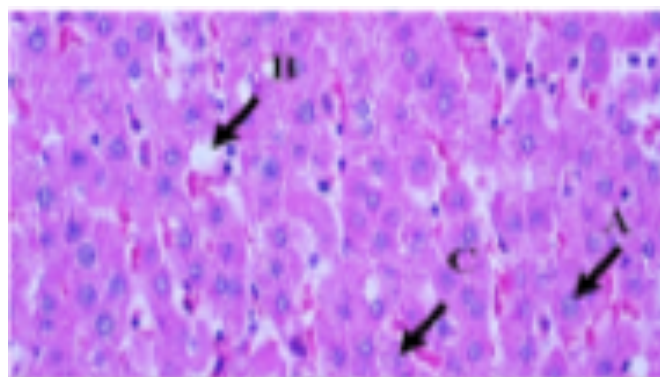

(d)

Gambaran histologi sel hati tikus wistar kelompok Dosis LS I menunjukkan sel mengalami perbaikan dengan berkurangnya degenerasi lemak dan nekrosis serta bertambahnya sel hepatosit normal. (A) Sel Normal, (B) Degenerasi lemak, (C) Nekrosis.

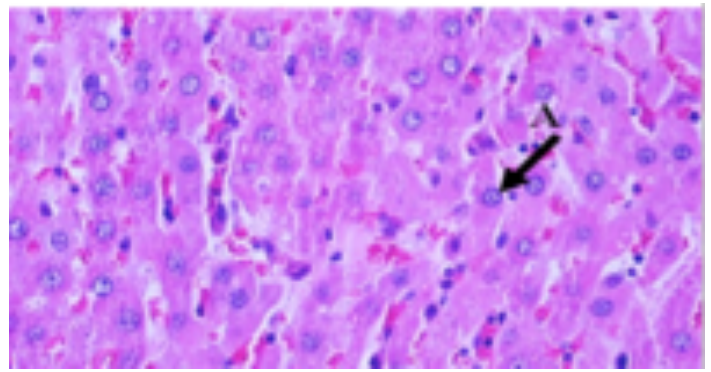

(f)

Gambaran histologi sel hati tikus wistar kelompok Dosis LS III menunjukkan sel mengalami perbaikan dengan berkurangnya degenerasi lemak dan nekrosis, serta bertambahnya sel hepatosit normal. (A) Sel Normal.

Gambar 1. Histologi Tikus Wistar dengan pembesaran 400x 


\subsubsection{Pengamatan histopatologi}

Preparat histopatologi diperiksa di bawah mikroskop masing-masing pada 5 lapang pandang mikroskopik. Pemeriksaan dengan mikroskop dilakukan dengan pembesaran 100x kemudian dilanjutkan dengan pembesaran 400x. Perubahan histopatologi yang diamati meliputi adanya degenerasi lemak dan nekrosis. ${ }^{6}$

\section{Hasil}

Secara visual gambar histopatologi tikus terdapat perubahan di parenkim hati seperti pada Gambar 1 dan Tabel 1. Perubahan ini terjadi pada perlakuan kelompok kontrol negatif, kelompok kontrol positif maupun kelompok antihiperlipidemia. Perbedaan antara keenam kelompok ditunjukkan oleh derajat keparahan kerusakan hati. Pada parenkim hati seluruh kelompok ditemukan hepatosit yang mengalami degenerasi lemak dan kematian sel.

\section{Pembahasan}

Pada penelitian ini dilakukan uji aktivitas ekstrak etanol lansau dengan tiga variasi dosis, secara umum hasil penelitian menunjukkan adanya perubahan gambaran histologi sel hati tikus pada kelompok normal, kelompok negatif, positif, dan kelompok perlakuan yang diberi ekstrak etanol lansau.

Hasil yang diperoleh pada kelompok negatif terlihat tingginya persentase sel degenerasi lemak yaitu $63 \%$ dan nekrosis $20 \%$ dan penurunan persentase hepatosit normal pada kelompok K(-) (Gambar 1a) hal ini membuktikan bahwa pemberian kolesterol dan lemak yang berlebihan dapat menyebabkan kerentanan hepatosit mulai dari degenerasi lemak hingga kematian sel. Pada perlakukan kelompok positif pada hewan coba seperti yang telihat pada (Gambar 1c), persentase hepatosit normal mengalami peningkatan sebesar 50\% dan lesio degenerasi lemak menurun menjadi 5\% dan nekrotik 5\%. Hal ini disebabkan karena berkurangnya jumlah agen penyebab kerusakan sel, yang ditimbulkan oleh asupan kolesterol asam lemak dan trigliserida. Pemberian simvastatin pada kelompok positif menyebabkan penurunan lesio degenerasi lemak di hati karena statin memiliki efek penurun LDL kolesterol terbesar sehingga statin dijadikan sebagai obat utama untuk mengatasi hiperkolesterolemia. Pada pemberian ektrak lansau dengan dosis $6,90 \mathrm{mg} / \mathrm{kgbb}$ (LS I) gambaran jaringan sel hati seperti pada (Gambar 1d) menunjukkan efektivitas yang hampir sama dengan kelompok $\mathrm{K}(+)$ dalam perbaikan sel hati dalam mengurangi degenerasi lemak dan nekrosis.

Hasil yang diperoleh pada gambar jaringan sel hati dari kelompok LS II (Gambar 1e) memiliki efektifitas yang hampir sama dengan kelompok positif untuk memperbaiki kerusakan sel hati dengan mengurangi jumlah degenerasi lemak dan nekrosis dan meningkatkan jumlah sel normal di hati.

Hasil yang diperoleh pada gambar jaringan sel hati kelompok LS III (Gambar 1f) memiliki efektifitas yang hampir sama dengan kelompok positif, bahkan kelompok LS III mengalami perbaikan yang lebih baik dalam perbaikan sel hati dalam mengurangi degenerasi lemak dan nekrosis.

Hasil uji skrining fitokimia Lansau yang dilakukan oleh Darmawan, dkk. ${ }^{7}$ menunjukkan bahwa Lansau memiliki kandungan senyawa flavanoid, saponin, dan tanin. Flavonoid merupakan senyawa metabolit sekunder yang termasuk senyawa fenolik alam, berpotensi sebagai antioksidan dan mempunyai bioaktifitas sebagai obat. Kandungan flavonoid dapat menurunkan kolesterol total, dapat menurunkan sekresi apo B dalam hepatosit dan juga menurunkan aktivitas dari enzim HMGKoA, sedangkan saponin dapat menurunkan penyerapan kolesterol, dan meningkatkan ekskresi fekal dari asam empedu yang merupakan produk sekresi kolesterol. ${ }^{8}$ Senyawa saponin bekerja dengan mengendapkan kolesterol dan ikut campur dalam sirkulai enterohepatik asam empedu yang membuat penyerapan kolesterol di usus terganggu. ${ }^{9}$ Kandungan senyawa tanin mampu mengurangi penimbunan kolesterol dalam darah dan mempercepat pembuangan kolesterol melalui feses. ${ }^{10}$ Aktivitas senyawa tanin dapat mencegah terjadinya gangguan keseimbangan antara produksi oksidan 
dan antiosidan terkait dengan konsumsi radikal bebas. Mekanisme senyawa tanin menurunkan kadar kolesterol total dengan menghambat oksidasi LDL. ${ }^{11}$

\section{Simpulan}

Ekstrak etanol lansau dapat mengurangi jumlah sel degenerasi lemak dan nekrosis serta meningkatkan jumlah sel hepatosit normal pada hati, dan persentase perbaikan sel hati terbanyak pada dosis III $(27,62 \mathrm{mg} /$ kgbb).

\section{Pustaka}

1. Maramis, R., Marie, K., Tanudjadja, G.N., Gambaran Histologi Aorta Tikus Wistar dengan Diet Lemak Babi Setelah Pemberian Ekstrak Daun Sirsak (Annona muricata L.), Jurnal E-Biomedik; 20142 (2).

2. RahmawatiSyukur, GeminiAlam, Mufida, Abdula Rahim, R.T., Aktivitas antiradikal bebas beberapa ekstrak tanaman familia fabacea. Jurnal of Chemical Information and Modeling, 2013; 53(9), 1689-1699

3. Gilman, Goodman and Gilman: Dasar farmakologi terapi. Jakarta: EGC, 2012; Edisi 10. Vol 2,.

4. Ruslin, Heny K, Sunandar I, Suryani, Nur Samsiar, Ardiyanti, Zulfikar T, Rahmad D, Elsa, The identification of pharmacognostic on the extraction of tradisional medicine to lansau of Muna ethnic of Southeast Sulawesi Province. IAJP 2017; 49(11), 4170-4177

5. Elfrida, E., Efek antihiperlipidemia ekstrak etanol $70 \%$ buah parijoto (Medinilla speciosa Blume) terhadap jaringan hati tikus putih jantan, 2015; UIN Syarif Hidayatullah, Jakarta.

6. Swarayana, I.M.I., I Wayan, S., dan I Ketut, B., Perubahan histopatologi hati mencit (Mus musculus) yang diberikan ekstrak daun ashitaba (Angelica keiskei), Buletin Veteriner Udayana. 2012; 4 (2).

7. Maramis, R., Marie, K., Tanudjadja, G.N., Gambaran histologi aorta tikus wistar dengan diet lemak babi setelah pemberian ekstrak daun sirsak (Annona muricata L.), Jurnal E-Biomedik. 2014; 2 (2).

8. Dimas, A. P., Rahmah, F. S dan Setyaningrum, T. R., Potensi antihiperlipidemia ekstrak etanol daun bayam merah (Amaranthus tricolor L.) terstandar secara in vivo Berdasarkan Parameter LDL (Low Density Lipoprotein), Jurnal Sains Farmasi \& Klinis. 2016; 2(2).

9. Kamesh, V., and Thangarajan, S., Antihypercholesterolemic effect of Bacopa monniera linn on high cholesterol diet induced hypercholesterolemia in rats, Asian Pasific Journal Of Tropical Medicine. 2012

10. Umarudin, S., dan Yuniastuti, A., Efektivitas ekstrak tanin seledri terhadap profil hiperkolesterolemi lipid tikus putih, Jurusan Biologi FMIPA Universitas Negeri Semarang Indonesia, Unnes Journal of Life Science. 2012

11. Desi Sartina. Pengaruh ektraksi etanol lansau terhadap histopatologi organ hati tikus putih wistar jantan yang mengalami hiperlipidemia. Skripsi UHO; 201 